\title{
Pemetaan Potensi Desa untuk Penguatan Badan Usaha Milik Desa dengan Pendekatan Asset Based Community-Driven Development
}

\author{
Kiky Srirejeki, Agus Faturahman, Warsidi, Permata Ulfah, Eliada Herwiyanti \\ Fakultas Ekonomi dan Bisnis.Universitas Jenderal Soedirman \\ Email: kiky.srirejeki@unsoed.ac.id
}

\section{Article Info}

Submitted: 4 Oktober 2019

Revised: 17 Oktober 2019

Accepted: 1 November 2019

Published: 2 Januari 2020

Keywords: asset-based community-driven development, village-owned enterprise, community service, village potential map.
Kata kunci: asset-based community-driven development, badan usaha milik desa, pengabdian masyarakat, peta potensi desa.

\begin{abstract}
Pliken Village is one of the few villages in Banyumas District that already has a Village Owned Enterprise (Badan Usaha Milik Desa/ BUMDes). However, after almost a year of its establishment, the impact of its existence is hard to measure. Currently, one of the Village Owned Enterprise's activity is the waste management, while it is still one of the main activity, the village government is now considering other activities that could be served as business expansion. To ensure the sustainability of village-owned enterprise's activity, the idea to expand the business should be based on rigorous planning and strategy. The community service activity was carried out to accomplish the objective by mapping village potential. This activity is a part of comprehensive planning and strategy to create sustainable village-owned enterprise. The activity was performed with the participation of village society which also represents the village diversity. We employed the assets based community-driven development approach to make sure that every member's potential was acknowledged and could be used to improve village development. The results indicate that gifts of individual, citizen's associations and local institutions are prominent factors to create a map of village potential. Further, the results suggest the improvement of capacity and management as well as village networks development are essential to strengthen the village owned enterprise.
\end{abstract}

Abstrak
Desa Pliken adalah salah satu desa di Kabupaten Banyumas yang
sudah memiliki Badan Usaha Milik Desa (BUMDes). Namun, setelah
hampir satu tahun berdiri, dampak keberadaannya sulit diukur. Saat
ini, salah satu kegiatan BUMDes adalah pengelolaan sampah, meskipun
masih menjadi kegiatan utama, pemerintah desa saat ini sedang
mempertimbangkan kegiatan lain untuk ekspansi aktivitas bisnis
BUMDes. Untuk memastikan keberlanjutan kegiatan perusahaan milik
desa, gagasan perluasan bisnis harus didasarkan pada perencanaan
dan strategi yang menyeluruh. Kegiatan pengabdian masyarakat
dilakukan untuk mencapai tujuan tersebut dengan melakukan


pemetaan terhadap potensi desa. Kegiatan ini merupakan bagian dari perencanaan dan strategi komprehensif untuk menciptakan BUMDes yang berkelanjutan. Kegiatan ini dilakukan dengan partisipasi masyarakat desa yang mewakili keragaman desa. Kami menggunakan pendekatan pembangunan berbasis masyarakat yang berbasis aset untuk memastikan bahwa setiap potensi anggota diakui dan dapat digunakan untuk meningkatkan pembangunan desa. Hasil menunjukkan bahwa bakat/potensi individu, organisasi warga dan lembaga lokal adalah faktor utama dalam penyusunan peta potensi desa. Lebih lanjut, hasilnya menunjukkan peningkatan kapasitas dan manajemen serta pengembangan jaringan desa sangat penting untuk penguatan BUMDes.

\section{PENDAHULUAN}

Sejak diberlakukan Undang-Undang No. 6 Tahun 2014 tentang Desa, salah satu kewajiban yang harus dilakukan desa adalah membentuk Badan Usaha Milik Desa (BUMDes). Keberadaan BUMDes dimaksudkan untuk mengelola usaha milik desa yang dapat digunakan sebagai wadah ekonomi produktif masyarakat desa yang disesuaikan dengan potensi serta kebutuhan masing-masing desa.

BUMDes adalah suatu lembaga/ perekonomian desa yang memiliki badan hukum yang dibentuk dan dimiliki oleh Pemerintah Desa, dikelola secara mandiri dan profesional dengan modal seluruhnya atau sebagian besar merupakan kekayaan desa yang dipisahkan. Menurut Peraturan Pemerintah Nomor 72 Tahun 2005 tentang Desa pasal 78 ayat 1, BUMDes dibentuk dengan tujuan untuk memperoleh keuntungan dan memberi kontribusi pada Pendapatan Asli Desa (PADes), memajukan perekonomian desa, serta meningkatkan kesejahteraan masyarakat desa.

Keberadaan BUMDes juga didukung dengan harapan dapat menjadi pengelola aset-aset desa dan sumberdaya ekonomi desa yang lain serta menjadi penggerak bagi pemberdayaan masyarakat. Menurut Permendesa Nomor 4 Tahun 2015 tentang Pendirian, Pengurusan dan Pengelolaan dan Pembubaran Badan Usaha Milik Desa, BUMDes didirikan dengan tujuan untuk memajukan perekonomian desa, serta meningkatkan kesejahteraan masyarakat desa. Dengan keberadaan BUMDes diharapkan desa dapat menjadi lebih mandiri dan masyarakat desa menjadi lebih sejahtera.
BUMDes diharapkan menjadi pilar kegiatan ekonomi di desa yang berfungsi sebagai lembaga sosial (social institution) dan komersial (commercial institution). BUMDes dalam konteks sebagai lembaga sosial berpihak kepada kepentingan masyarakat melalui kontribusinya dalam mengatasi masalah-masalah sosial yang ada di desa maupun sebagai penyedia pelayanan sosial. Sedangkan perannya sebagai lembaga komersial, BUMDes diharapkan dapat menjadi kontributor dalam peningkatan Pendapatan Asli Desa (PADes) (Srirejeki, 2015).

Fungsi BUMDes sangat strategis dalam membangun usaha ekonomi desa. Dalam sistem kerjanya, BUMDes dapat terdiri dari unit-unit usaha yang berbadan hukum dan berbentuk lembaga bisnis yang kepemilikan sahamnya berasal dari BUMDes dan masyarakat. BUMDes juga dapat membentuk unit usaha berupa perseroan terbatas (PT) ataupun Lembaga Keuangan Mikro.

Selain itu motivasi dari kewajiban pendirian BUMDes adalah sebagai sumber untuk peningkatan Pendapatan Asli Desa (PADes) (Srirejeki, 2018). Dalam konstruksi berpikir tersebut, apabila PADes dapat ditingkatkan dari BUMDes, maka kondisi tersebutakan mendorong setiap Pemerintah Desa untuk memberikan respon positif atas pendirian BUMDes.

Secara legal dan teoritis selayaknya setiap desa memiliki BUMDes, tidak hanya karena hal tersebut adalah kewajiban konstitusi desa atas amanat undang-undang tetapi juga karena manfaat yang akan diperoleh desa dengan adanya BUMDes. Namun, realita yang terjadi di lapangan tidaklah demikian. 
Desa Pliken merupakah salah satu desa yang secara formal sudah memiliki BUMDes namun pemanfaatannya belum maksimal. Hal ini terlihat minimnya kegiatan BUMDes. Padahal salah satu tujuan pendirian BUMDes adalah untuk membantu meningkatkan kesejahteraan desa, terutama dari kesejahteraan ekonomi. Belum dimanfaatkannya BUMDes secara maksimal sebagai motor ekonomi desa tidak terlepas dari ketiadaan peta potensi desa. Peta potensi desa menjadi instrumen yang sangat penting sebagai petunjuk untuk BUMDes membuat program kerja atau kegiatan. Dengan adanya peta potensi desa, Desa dapat membuat strategi prioritas pembangunan desa melalui pendayagunaan BUMDes (Abidin, 2017).

Dalam melakukan pemetaan potensi desa sangat penting untuk juga melibatkan partisipasi masyarakat secara aktif. Aspirasi dan masukan dari berbagai elemen masyarakat dapat menjadi sumber gagasan atas berbagai proyek yang dapat dikerjakan oleh BUMDes. Penelitian yang dilakukan oleh Mwiru (2015) menunjukkan bahwa partisipasi masyarakat dalam kegiatan pembangunan masyarakat sangat penting dalam meningkatkan rasa kepemilikan, memastikan alokasi dana tepat sasaran dan juga dapat mempercepat proyek pembangunan yang dilaksanakan. Hal senada juga diutarakan oleh Imparto \& Ruster (2003:15) yang menyatakan bahwa partisipasi masyarakat sangat penting dalam program pembangunan yang berkelanjutan, karena para pemangku kepentingan akan dilibatkan dalam proses pengambilan keputusan dalam setiap tahapan pembangunan proyek sehingga kendala pembangunan dan juga kebutuhan terhadap pembangunan tersebut akan dapat lebih mudah dimengerti. Maka dalam konteks pengabdian ini, partisipasi dari masyarakat ini sangat penting untuk menumbuhkan rasa memiliki terhadap proyek dan kegiatan yang akan dilaksanakan BUMDEs. Keterlibatan dari berbagai komponen masyarakat ini penting dilakukan dari awal, yaitu sejak tahap perencanaan. Sosialisasi dan diskusi yang dilakukan dalam bentuk diskusi kelompok terarah dapat menjadi metode yang efektif untuk menampung aspirasi, gagasan dan masukan dari masyarakat.

Kegiatan Pengabdian kepada Masyarakat
(PPM) ini sangat penting karena pembentukan BUMDes harus direncanakan secara matang dan komperhensif dengan mempertimbangkan potensi dan urgensi desa. Saat ini masih banyak desa yang belum mengetahui bagaimana melakukan pemetaan atas potensi desanya dan bagaimana menyusun prioritas atas potensipotensi yang telah disusun. Kegagalan dalam menyusun perencanaan akan sangat fatal, mengingat pembangunan BUMDes bukanlah rencana jangka pendek namun juga rencana jangka panjang.

\section{METODE}

pada masyarakat dilakukan $\begin{array}{r}\text { Pelaksanaan dengan } \\ \text { pegiatan }\end{array}$ mengkombinasikan beberapa metode kegiatan antara lain dengan cara (1) pemberian materi terkait pemahaman pentingnya potensi desa, (2) metode diskusi kelompok terarah yang dilakukan dengan membagi masyarakat dalam kelompokkelompok sesuai dengan bidang dan minat serta profesinya. Beberapa kelompok yang dilibatkan dalam diskusi antara lain dari Gabungan Kelompok Tani (GAPOKTAN), kelompok diskusi dari para pelaku UMKM, dan lain sebagainya. Kegiatan pengabdian dilakukan di Pendopo Desa Pliken, Kecamatan Kembaran, Kabupaten Banyumas pada tanggal 23-25 September 2019.

Materi terkait potensi desa yang disampaikan diberikan pada awal sesi. Isi materi membahas mengenai pentingnya pemetaan terhadap potensi desa, lalu strategi melakukan pemetaan potensi desa dan pentingnya partisipasi dari masyarakat desa untuk berkontribusi dalam melakukan pemetaan ini. Sesi pemberian materi ini dilakukan dengan mengkombinasikan metode ceramah-diskusi.

Peserta yang hadir pada acara sosialisasi dan diskusi antara lain kepala desa, sekretaris desa dan para perangkat desa, para kepala dusun, ketua dan perwakilan dari berbagai kelompok masyarakat misalnya: kelompok tani, kelompok peternak ikan, kelompok pengusaha (Usaha Mikro Kecil dan Menengah) UMKM, pengrajin tempe dan olahannya, serta tokoh masyarakat dan perwakilan pemuda desa dari karang taruna. Masing-masing dari kelompok melakukan diskusi intensif yang dibantu oleh fasilitator yang bertugas memandu jalannya 
diskusi dan mencatat poin penting dari diskusi. Keseluruhan peserta beserta dengan fasilitator berjumlah 35 orang.

Masing-masing fasilitator memiliki daftar pertanyaan yang digunakan untuk memicu diskusi. Pertanyaan ini sifatnya tidak baku artinya tergantung dari dinamika diskusi yang terjadi. Pertanyaan juga disesuaikan dengan karakteristik kelompok, sehingga pertanyaan untuk tiap-tiap kelompok berbeda-beda. Namun demikian, secara garis besar pokok bahasan yang dibahas dalam diskusi di setiap kelompok antara lain (1) apa yang saat ini menjadi kegiatan kelompok masyarakat (2) siapa saja pihak yang terlibat dalam kegiatan kelompok masyarakat, (3) kegiatan unggulan bisa berupa produk/jasa yang sangat ingin dikembangkan (3) tantangan dalam pengembangkan produk/jasa yang diinginkan.

Kegiatan diskusi dibantu oleh fasilitator yang bertugas untuk memastikan jalannya diskusi berjalan lancar. Fasilitator juga bertugas untuk merekam dan mencatat poin-poin penting dari diskusi yang berlangsung. Sesi diskusi kelompok terarah pada masing-masing kelompok berlangsung selama kurang lebih satu setengah jam.

Penggunaan metode diskusi kelompok terarah dalam kegiatan pengabdian masyarakat karena dianggap dapat meningkatkan kesadaran para peserta diskusi terkait dengan hal-hal yang menjadi bahasan dalam diskusi (Ljunggren, Huang \& Johansson, 2014) serta dapat meningkatkan partisipasi dalam pemberdayaan masyarakat (Sharma, 2005). Dalam kegiatan pengabdian ini, diskusi diharapkan dapat meningkatkan kesadaran para peserta diskusi, yaitu perwakilan elemen masyarakat, mengenai potensi dan kapasitas yang dimiliki.

\section{HASIL DAN PEMBAHASAN}

Pada kegiatan pengabdian masyarakat ini tujuan utama adalah untuk mendapatkan informasi mengenai potensi desa yang digali dengan cara partisipatif dari masyarakat. Pendekatan yang digunakan adalah dengan Asset Based Community-Driven Development (ABCD). Pendekatan ABCD dikembangkan oleh John L. McKnight dan John P. Kretzmann dari Northwestern University, Amerika
Serikat. Metode ABCD adalah pendekatan yang menitikberatkan pada penyusunan strategi untuk pembangunan berkelanjutan yang berbasis masyarakat. Pendekatan ABCD ini tidak hanya terkait pada mobilisasi masyarakat dalam pembangunan di desa tetapi juga bagaimana mengidentifikasi dan membangun serta menciptakan aset lokal desa menjadi lebih berdayaguna.

Menurut Cunningham (2012:14) pembangunan berbasis masyarakat adalah proses dimana masyarakat secara bersamasama memiliki motivasi untuk menyelesaikan sebuah masalah atau menciptakan suatu peluang, dengan cara memobilisasi diri mereka sendiri dan mengandalkan sumber daya yang dimiliki secara independen dengan sedikit mungkin campur tangan dari pihak luar. Apabila pembangunan berbasis masyarakat ini sudah dilakukan maka diharapkan dapat mendorong masyarakat desa menjadi masyarakat yang berdaya, yaitu karakateristik masyarakat yang memiliki kemampuan untuk mengidentifikasi, memobilisasi dan memecahkan permasalahan sosial (Goodman et al., 1998).

Dalam pelaksanaan metode $A B C D$, pada kegiatan pengabdian masyarakat ini kami menggunakan dua alat utama, yaitu dengan melaksanakan (1) pemberdayaan inventaris dengan cara diskusi kelompok terarah, dan (2) pemetaan aset dan (3) penguatan BUMDes

\section{Pemberdayaan Inventaris dengan Diskusi Kelompok Terarah}

Kegiatan diskusi kelompok terarah dilakukan sebagai metode untuk melakukan pemberdayaan inventaris dengan tujuan untuk mengakses informasi yang masyarakat ketahui baik secara sadar maupun tidak sadar mengenai potensi desanya. Harapannya dasar dari informasi yang didapatkan dari pemberdayaan inventaris ini membuat masyarakat yakin bahwa setiap anggota masyarakat adalah aset yang berharga bagi pembangunan desa yang berkelanjutan. Metode diskusi kelompok terarah merupakan metode yang paling efektif dan efisien untuk menggali informasi terkait potensi masyarakat dibandingkan dengan metode wawancara maupun survei dengan kuesioner (Freitas, Oliveira, Jenkins, \& Popjoy, 1998). Hal ini karena dengan metode diskusi kelompok 
terarah diharapkan masing-masing anggota kelompok dapat melakukan diskusi dan menggali apa yang menjadi potensi masing-masing dan antar anggota kelompok juga sekaligus dapat melakukan konfirmasi terhadap pernyataan anggota yang lain dalam kelompok. Sedangkan dalam metode survey atau kuesioner akan sulit untuk memverifikasi jawaban dari peserta. Diskusi dilakukan sesuai dengan kelompokkelompok masyarakat yang berbeda-beda. Informasi mengenai kelompok peserta diskusi disajikan pada Tabel 1.

Informasi yang digali terkait pemberdayaan inventaris meliputi pertama, informasi keahlian yang meliputi keahlian-keahlian dari berbagai elemen masyarakat desa, termasuk juga mengidentifikasi siapa saja anggota masyarakat yang memiliki keahlian-keahlian tersebut. Daftar anggota masyarakat dengan keahliannya masing-masing kelak dapat dimanfaatkan apabila dibutuhkan fasilitator kegiatan tertentu maupun penggerak kegiatan yang ada pada komunitas masyarakat.

Informasi kedua yang digali pada kegiatan pemberdayaan inventaris adalah kemampuan yang bisa dilakukan oleh komunitas. Dalam tahapan ini masyarakat mengidentifikasi apa saja pekerjaan yang bisa dikerjakan secara kelompok. Masyarakat desa terkenal dengan nilai gotong-royong yang masih kental. Nilai sosial ini dapat digunakan juga sebagai modal sosial untuk menggerakan masyarakat. Informasi ini diharapkan dapat dibagikan kepada masyarakat secara luas supaya ketika ada masyarakat yang tertarik untuk bergabung mereka akan memilih sesuai dengan kelompok yang diminatinya.

Tabel 1. Informasi Profil Peserta FGD

\begin{tabular}{cl}
\hline Grup/Kelompok & Entitas Kelompok \\
\hline 1 & Petani \\
2 & Petani Ikan Gurame \\
3 & Karang Taruna \\
4 & Tokoh Masyarakat \\
5 & Pengrajin tempe \\
6 & UMKM \\
7 & Pengurus BUMDes \\
\hline
\end{tabular}

\section{Pemetaan Aset}

Dalam membuat pemetaan aset desa digunakan rerangka yang dikembangkan oleh Kretzmann \& McKnight (1993), dengan membagi pemetaan aset dalam tiga kategori, yaitu gifts of individuals, citizen's associations (organisasi kelompok masyarakat), dan local institutions (institusi lokal desa). Gambaran pemetaan aset desa dapat dilihat pada gambar 1 .

Dari hasil diskusi kelompok terarah, diperoleh gambaran umum mengenai potensi desa. Dalam level paling kecil ada banyak potensi dari berbagai elemen masyarakat, misalnya di desa terdapat ahli pertanian. Tokoh masyarakat yang juga ahli dalam bidang pertanian ini seringkali memberikan penyuluhan kepada petani di Desa Pliken, misalnya terkait dengan sosialisasi metode jajar legowo, yaitu sistem penanaman padi dengan cara mengatur jarak tanam. Penanaman padi dengan metode ini telah terbukti meningkatkan hasil padi dibandingkan dengan metode tanam padi tradisional. Secara aktif ahli pertanian ini menjadikan sistem penanaman padi yang dilakukan oleh petani di Desa Pliken. Dari hasil diskusi juga diketahui bahwa salah satu inisiasi yang bisa dikembangkan untuk tahun ini dan yang akan datang adalah usaha untuk menjadi produsen benih padi yang berkualitas. Hal ini dilatarbelakangi oleh kebutuhan benih padi yang sangat banyak di Kabupaten Banyumas sendiri. Apabila GAPOKTAN Desa Pliken dapat menjawab permintaan pasar tersebut, maka tentu tidak hanya padi yang akan dipanen, tetapi juga benihbenih padi yang dijual dan disebarkan ke desa atau daerah yang lain.

Selain adanya ahli pertanian yang menggerakan GAPOKTAN, terdapat pula anggota masyarakat yang kaya akan pengalaman yang juga mendorong aktifnya kegiatan koperasi untuk petani ikan gurameh. Pada awalnya usaha ikan gurameh adalah usaha individual yang dilakukan oleh salah seorang masyarakat. Namun, karena kemampuannya untuk mengembangbiakan gurame yang baik, akhirnya usaha ini berkembang dan berubah menjadi koperasi dengan nama koperasi Mulya Sari. Dengan model koperasi ini, para petani ikan gurameh dapat bekerja secara bersama-sama untuk mengembangbiakan ikan gurame dan memasarkan hasil panen ikan guramehnya. 


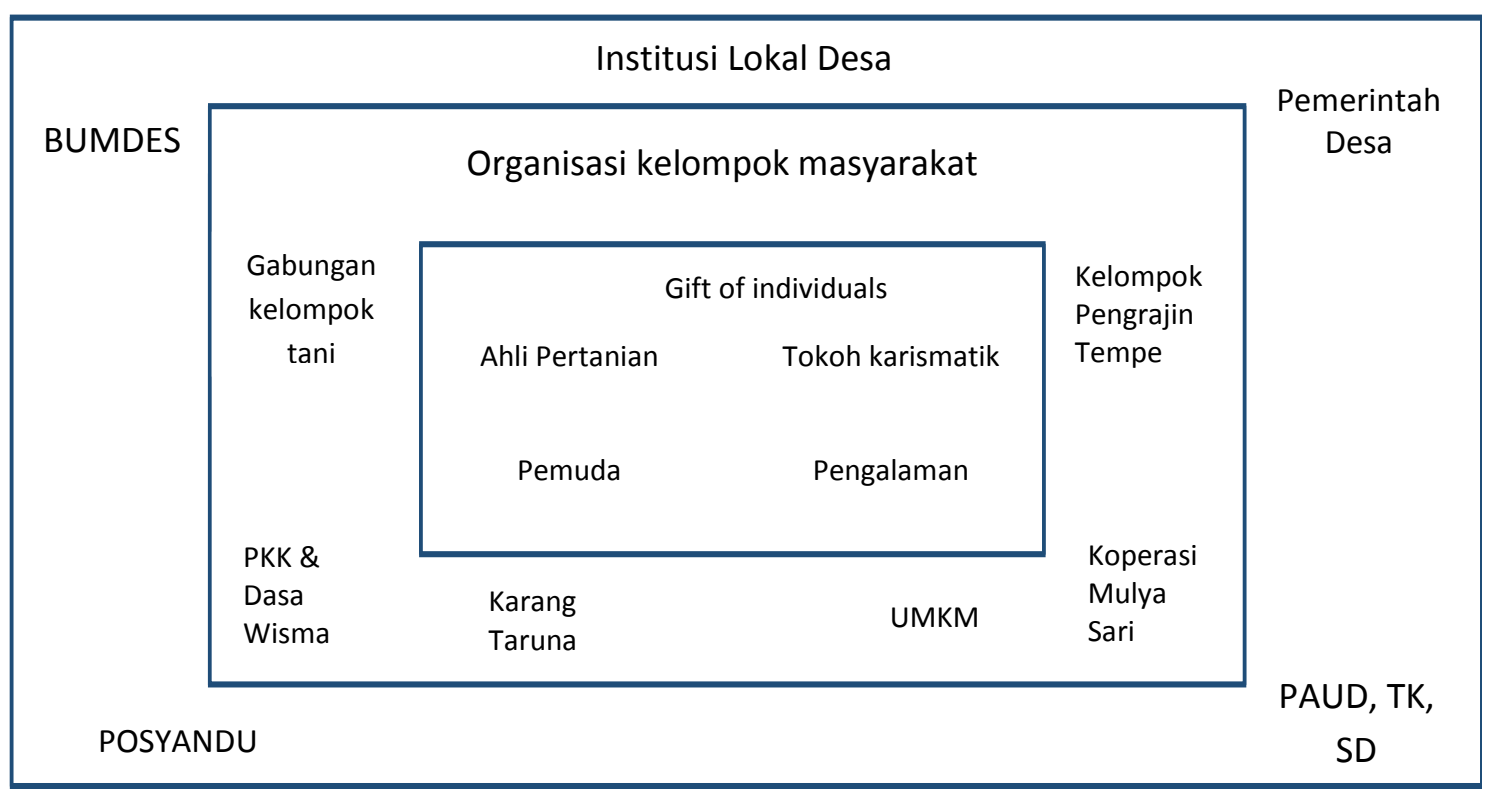

Gambar 1. Potensi Desa

Dalam kerangka yang dikembangkan oleh Kretzmann \& McKnight (1993), setiap anggota masyarakat dianggap memiliki kapasitas untuk berkontribusi di lingkungan masyarakat. Dengan pendekatan ABCD tersebut, setiap anggota masyarakat diakui keunikannya dan setiap keunikan tersebut dianggap sebagai aset yang dapat membantu pengembangan komunitas yang berkelanjutan. Misalnya, pemuda, para pemuda dapat menjadi aset yang sangat berharga dan dapat berkontribusi dengan caranya sendiri. Pemuda dapat memberikan gagasan dan ide yang inovatif dalam rencana pembangunan desa. Para pemuda dengan energi yang besar juga dapat menjadi penggerak rencana pembangunan desa. Di desa Pliken para pemuda ini banyak yang menjadi pelaku UMKM dan pengrajin tempe. Tempe adalah salah satu komoditas unggulan di Desa Pliken, setiap harinya konsumsi kedelai untuk produksi tempe mencapai 15 ton. Desa Pliken juga menjadi produsen tempe terbesar di wilayah Kabupaten Banyumas. Para pemuda yang bekerja sebagai pengrajin tempe ini mengerjakan hampir seluruh rantai produksi hingga penjualan tempe.

Di level yang kedua, yaitu organisasi kelompok masyarakat. Terdapat cukup banyak organisasi kelompok masyarakat di Desa Pliken. GAPOKTAN, kelompok pengrajin tempe,Program Kesejahteraan Keluarga (PKK) dan Dasa Wisma, Karang Taruna, UMKM dan Koperasi Mulya Sari adalah diantaranya. Selain organisasi kelompok masyarakat tersebut, terdapat pula beberapa organisasi kelompok masyarakat yang terbentuk bukan karena minat atau ketertarikan tertentu, tetapi merupakan bagian dari adat dan budaya setempat, misalnya kelompok pengajian yang seringkali mengadakan pengajian rutin seminggu sekali. Anggota kelompok pengajian ini meliputi hampir semua anggota masyarakat.

Organisasi kelompok masyarakat ini menjadi penggerak para anggota masyarakat untuk dapat melakukan aktivitas yang diminatinya dengan lebih terencana. Dengan berkumpulnya para anggota masyarakat dalam organisasi kelompok masyarakat kekuatan yang dimiliki menjadi lebih besar, gagasan yang muncul juga menjadi lebih beragam.

Pada level yang tertinggi adalah institusi lokal desa. Berbeda dengan organisasi kelompok masyarakat, institusi lokal desa beroperasi pada level desa dan melayani hampir semua masyarakat desa. Selain institusi pemerintah desa yang merupakan tingkatan tertinggi dalam piramida institusi lokal desa, ada pula sekolah yang dimiliki dan dikelola oleh desa, misalnya Pendidikan Anak Usia Dini (PAUD) dan Taman Kanak-kanak (TK) yang menjadi tempat pendidikan dini bagi masyarakat setempat. Selain itu terdapat pula Pos Pelayanan Terpadu (Posyandu) yang berada di komplek balai desa yang memberikan pelayanan kesehatan dasar untukmasyarakat. Desa Plikenjugatelah memiliki BUMDes yang berfokus pada pengelolaan 
sampah. Hal ini dilatarbelakangi oleh gagasan menyelesaikan masalah lingkungan (sampah) dan juga menggerakan masyarakat untuk serta aktif menanggulangi masalah sampah (sosial). Namun demikian, meskipun secara formal BUMDes sudah terbentuk, aktivitas, output dan dampak dari kegiatan BUMDes belum terlalu terlihat dampaknya. Oleh karenanya diharapkan dengan pemetaan potensi desa ini, dapat menjadi langkah dalam perumusan strategi jenis usaha apa yang bisa dikembangkan oleh BUMDes di masa yang akan datang.

\section{Penguatan BUMDes}

BUMDes diharapkan dapat menjadi salah satu fasilitas untuk menggerakan ekonomi desa dan membantu memecahkan masalah sosial dan lingkungan yang ada di desa. Saat ini Desa Pliken telah memiliki BUMDes namun relatif belum menghasilkan secara finansial karena aktivitas yang dilakukan juga masih terbatas. BUMDes Desa Pliken sementara ini berfokus pada pengelolaan sampah, namun keterbatasan alat pengelolaan sampah sepertinya menjadi salah satu kendala terhambatnya aktivitas. Pada tahapan ini maka penguatan BUMDes menjadi penting untuk dilakukan.

Berdasarkan pada hasil diskusi kelompok terarah fokus penguatan BUMDes dapat difokuskan pada tiga hal utama. Yang pertama adalah pemetaan aset desa, kedua adalah peningkatan kapasitas pengelolaan dan manajemen dan ketiga adalah penguatan jaringan antar BUMDes. Pertama yaitu pemetaan aset desa menjadi salah satu hal substantif yang dilakukan sebagai upaya penguatan BUMDes. Dalam pemetaan aset desa dapat diketahui apa saja produk atau jasa yang menjadi unggulan desa, selain itu keahlian dan kapasitas apa saja yang dimiliki oleh anggota masyarakat yang bisa dimanfaatkan dan dikembangkan serta nilai-nilai sosial masyarakat yang bisa digerakan untuk mendorong terjadinya perubahan sosial. Dari hasil pemetaan aset desa tersebut, dibuat desain pemberdayaan inventaris yang bertujuan untuk penguatan BUMDes. Hasil desain penguatan BUMDes disajikan pada gambar 2 .
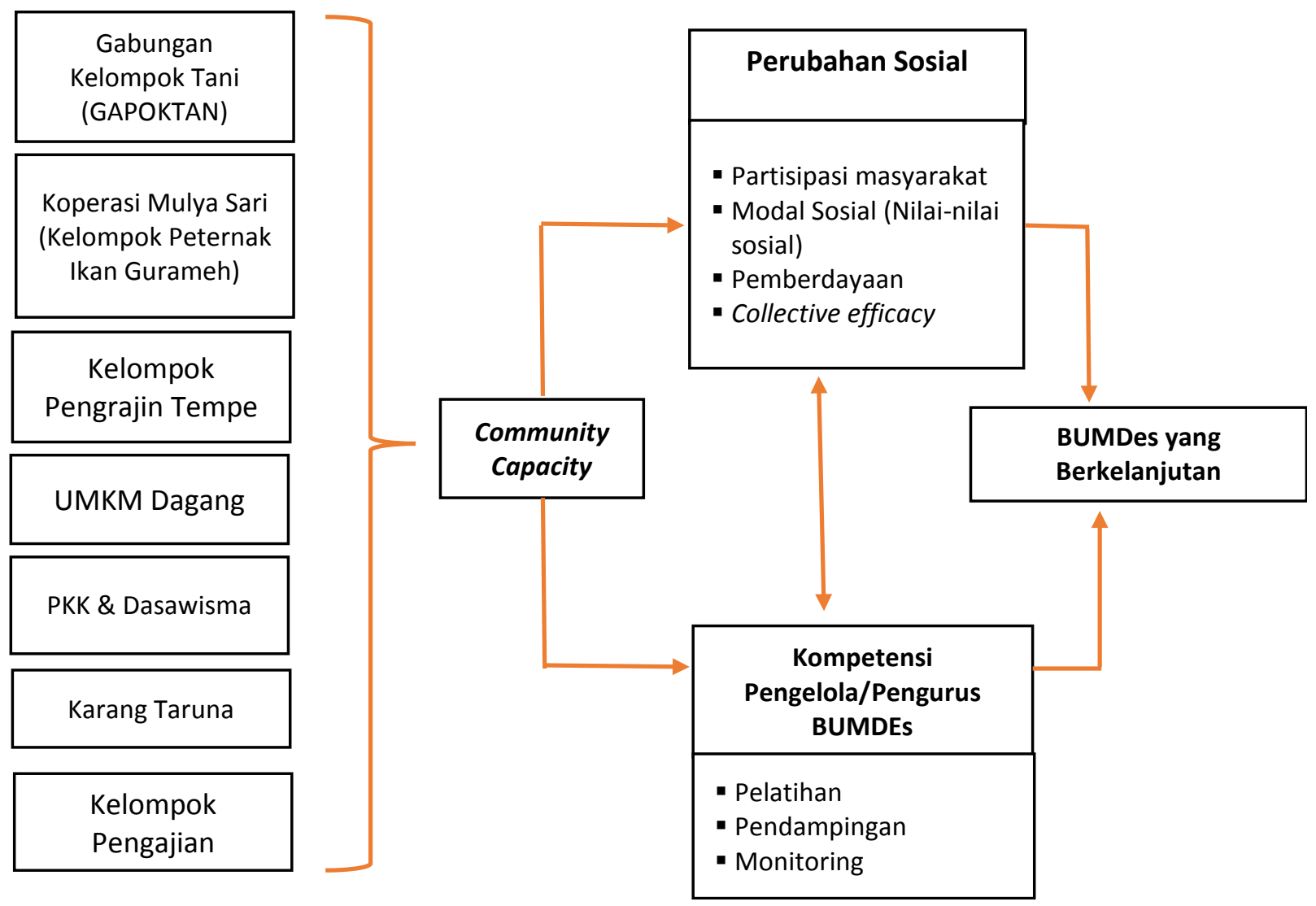

Gambar 2. Rerangka Penguatan BUMDEs

(Sumber: Hasil Analisis diskusi kelompok terarah di Desa Pliken) 
Hasil analisis pemetaan desa menunjukkan ada banyak alternatif kegiatan yang dapat dilakukan oleh BUMDes. Desa Pliken adalah produsen tempe terbesar di wilayah Kabupaten Banyumas, dengan fakta ini saja BUMDes dapat melibatkan diri untuk mengkoordinir dan memfasilitasi para pengrajin tempe. Selama ini pengrajin tempe melakukan aktivitas mulai dari produksi hingga penjualan secara mandiri oleh masing-masing pengrajin tempe. Meskipun praktik ini sudah berjalan dalam kurun waktu yang sangat lama, namun apabila ditinjau dari sisi efisiensi sangat tidak menguntungkan. Para pengrajin tempe menghabiskan hampir seluruh waktunya mulai dari pagi hari hingga malam hari untuk membagi aktivitas yang sebenarnya bisa dikoordinir oleh BUMDes.

Salah satu rekomendasi kegiatan pengabdian ini adalah BUMDes menjadi pemasar dari produk-produk tempe di Desa Pliken. BUMDes dapat menjajaki untuk menjadi distributor tempe dan juga mendirikan toko yang menjual hasil-hasil olahan tempe menjadi lebih menarik dan bernilai jual tinggi di pasar. Keahlian untuk membuat hasil olahan tempe pun sudah dimiliki oleh para pengrajin tempe, namun karena keterbatasan tenaga dan waktu selama ini mereka hanya berfokus pada produksi tempe mentah. Apabila jalur distribusi dan pemasaran produk dapat dialihkan kepada BUMDes, para pengrajin tempe dapat memiliki waktu yang lebih banyak untuk mengkreasikan tempe dalam berbagai olahan tempe yang memiliki nilai jual lebih tinggi. Keahlian yang selama ini dimiliki dapat didayagunakan dan dimanfaatkan untuk pengembangan kegiatan ekonomi. Dengan ini, tidak hanya pengrajin tempe yang mendapatkan keuntungan tetapi juga pemerintah desa melalui BUMDes. Kegiatan menjadi distributor atau pemasar produk olahan tempe yang dilakukan oleh BUMDes relatif lebih murah karena tidak membutuhkan alat tertentu atau keahliaan tertentu.

Selain penjadi pemasar produk tempe dan olahannya, BUMDes juga dapat memasarkan hasil panen ikan gurame dan olahan ikan gurame yang dihasilkan oleh koperasi Mulya Sari. Sama halnya dengan para pengrajin tempe, para peternak ikan gurame juga selama ini lebih banyak menjual hasil panen ikan gurame, meskipun sebenarnya keahlian untuk pengolahan ikan gurame juga sudah dimiliki. Namun, karena khawatir tidak adanya pasar yang akan menerima hasil olahan ikan gurame, selama ini para peternak ikan hanya berfokus pada panen ikan saja. Olahan hasil ikan gurame juga akan memiliki nilai jual yang tinggi dibandingkan dengan hanya menjual ikan gurame mentah. Keahlian yang dimiliki para peternah ikan gurame juga dapat disalurkan dan dikembangkan.

Hal yang serupa juga berlaku untuk GAPOKTAN. Salah satu program yang saat ini sedang dikembangkan GAPOKTAN adalah pembibitan benih padi sebagai komoditas selain padi. BUMDes dapat menjadi pemasar dan membuka jejaring untuk distribusi benih padi serta peningkatan kualitas benih padi. BUMDes dapat berperan dalam fasilitasi GAPOKTAN untuk meningkatkan kualitas pembibitan benih padi.

Fokus penguatan yang kedua adalah peningkatan kapasitas pengelolaan dan manajemen BUMDes. Hasil dari pemetaan aset desa, saran peningkatan kapasitas pengelolaan dan manajemen BUMDes bisa dimulai berkolaborasi dengan para pemuda desa yang bergabung dalam kelompok karang taruna. Kolaborasi bisa dilakukan misalnya terkait pelatihan pemasaran yang efektif. Melatih pemuda relatif lebih mudah dibandingkan dengan melatih pengurus formal BUMDes dengan usia yang tidak muda lagi. Para pemuda ini terbiasa menggunakan gawai dan lebih aktif di dunia maya melalui sosial media dibandingkan dengan generasi pendahulunya. Para pemuda ini juga memiliki energi yang lebih banyak dan juga ide yang lebih kreatif yang bisa diberdayagunakan untuk memasarakan produkproduk unggulan desa kepada pihak luar desa. Pemanfaatan metode berdagang melalui media elektronik (e-commerce) juga dapat digunakan sebagai langkah awal untuk memasarkan produk-produk unggulan desa.

Fokus penguatan yang ketiga adalah untuk menguatkan jejaring antar BUMDes. Jejaring ini diperlukan sebagai mitra BUMDes. Penguatan jejaring antar desa bisa dilakukan dengan asosiasi BUMDEs. Dengan cara ini diharapkan dapat meningkatkan hubungan antara BUMDes termasuk juga untuk memperluas pemasaran 
produk unggulan desa dan menjadi wadah untuk komunikasi antar pengelola dan pengurus BUMDes. Dengan penguatan jejaring ini, diharapkan BUMDes di Desa Pliken juga dapat mengambil pelajaran dari pengalaman yang sudah dilakukaan oleh BUMDes lain.

Penguatan BUMDes yang berkelanjutan juga tidak melupakan aspek pentingnya perubahan sosial yang mendukung, misalnya partisipasi dari masyarakat pada setiap pengambilan keputusankeputusan penting yang mempengaruhi masa depan desa. Selain itu penting pula penguatan modal sosial berupa nilai-nilai sosial sebagai katalisator inisiasi pembangunan desa. Pemberdayaan masyarakat yang inklusif juga menjadi komponen penting yang harus diperhatikan. Perubahan sosial juga harus diarahkan untuk menciptakan efikasi kolektif yaitu menciptakan masyarakat yang memiliki keyakinan bersama terhadap kemampuan untuk mengatur dan melaksanakan program yang diperlukan untuk mencapai tujuan bersama. Pentingnya efikasi kolektif diperlihatkan pada beberapa penelitian misalnya oleh Goncalo, Polman \& Maslach (2010) yang menyatakan bahwa kelompok yang memiliki efikasi kolektif yang tinggi akan lebih suskes dimasa yang akan datang dibandingkan dengan kelompok yang memiliki efikasi kolektif rendah. Hal ini karena kelompok dengan efikasi kolektif yang tinggi lebih berani untuk menetapkan tujuan yang lebih besar dan menantang. Penelitian yang lain juga dilakukan oleh Greenlees, Nunn, Graydon, \& Maynard (1999) yang mengungkapkan bahwa kelompok dengan efikasi kolektif yang tinggi cenderung lebih banyak mengerahkan usaha dan bertahan lebih lama dalam menghadapi kesulitan dan tantangan yang dihadapi.

\section{SIMPULAN}

Kegiatan pengabdian masyarakat di Desa Pliken dalam rangka melaksanakan pemetaan potensi desa untuk penguatan BUMDes yang berkelanjutan dilakukan selama beberapa hari. Tujuan penguatan BUMDes yang berkelanjutan dilakukan dengan tiga fokus utama, yaitu pemetaan aset atau potensi desa, kedua adalah peningkatan kapasitas pengelolaan dan manajemen BUMDes dan ketiga adalah penguatan jaringan antar BUMDes.
Pemetaan potensi desa dilakukan dengan pendekatan Asset Based Community-Driven Development (ABCD) yaitu pendekatan untuk pengembangan masyarakat yang berkelanjutan yang menitikberatkan pada penyusunan strategi berbasis masyarakat dengan cara mengkapitalisasi aset-aset yang ada di masyarakat. Dalam pendekatan ini, semua anggota masyarakat dianggap memiliki aset untuk berkontribusi pada pembangunan desa. Metode kegiatan dilakukan dengan melakukan diskusi kelompok terarah yang dihadiri oleh berbagai elemen masyarakat, mulai dari GAPOKTAN, kelompok petani ikan, karang taruna, pelaku UMKM dan para pengrajin tempe. Diskusi kelopom terarah dianggap metode yang paling efektif dan efisien dibandingkan dengan metode wawancara dan atau survery kueioner. Kegiatan diskusi yang dilaksanakan mendapat antusiasme yang baik dari berbagai elemen masyarakat. Tidak ada hambatan berarti terkait pelaksanakan kegiatan, selain bahwa kegiatan harus dilaksanakan malam hari sehingga selesainya kegiatan pun seringkali hingga menjelang tengah malam.

Dalam diskusi ini dihasilkan peta potensi desa yang mengikuti kerangka Kretzmann \& McKnight (1993). Peta potensi desa dibagi kedalam tiga kategori, yaitu potensi individu, organisasi kelompok masyarakat, dan institusi lokal desa.

Hasil dari peta potensi desa menunjukkan bahwa kategori potensi individu, Desa Pliken memiliki banyak anggota masyarakat yang memiliki keahlian-keahlian yang dapat diberdayagunakan, misalnya ahli pertanian, ahli perikanan, pengrajin tempe dan olahannya serta para tokoh masyarakat yang karismatik dan memiliki pengalaman yang kaya. Kategori yang kedua adalah organisasi kelompok masyarakat diisi oleh banyak komunitas-komunitas masyarakat yang sudah solid, antara lain GAPOKTAN, Koperasi peternak ikan gurame, PKK serta karang taruna yang menaungi komunitas pemuda desa. Pada kategori yang ketiga terdapat institusi lokal desa yang juga sudah mapan, misalnya adanya pemerintah desa yang akomodatif dan posyandu. Ada pula institusi lokal desa yang berpotensi untuk dikembangkan lebih baik lagi, yaitu BUMDes. berupaya 
untuk melakukan inovasi dengan tidak hanya menghasilkan panen padi tetapi juga menjadi produsen benih padi. Tidak hanya GAPOKTAN, Koperasi Mulya Sari yang menaungi petani ikan gurame juga berkembang menjadi salah satu koperasi yang diandalkan untuk menjadi tempat pengembangbiakan dan pemasaran ikan gurame.

Peningkatan kapasitas pengelolaan dan manajemen BUMDes dapat dimulai dengan bekerjasama dan berkolaborasi dengan para pemuda dalam komunitas karang taruna. Hal ini merupakan langkah yang efisien untuk menjadikan BUMDes sebagai agen pemasaran produk-produk unggulan desa. Dengan cara ini para pengrajin tempe dapat lebih berfokus untuk memproduksi tempe dan juga hasil olahan tempe yang selama ini belum dilakukan karena keterbatasan waktu dan tenaga. Selain itu peternak ikan gurame juga dapat menggunakan keahlian yang sudah dimiliki untuk juga membuat olahan produk dari ikan gurame. Olahan produk tempe dan ikan gurame memiliki nilai jual yang lebih tinggi sehingga secara finansial lebih menguntungkan. BUMDes diharapkan dapat mengambil peran sebagai agen pemasaran atas produk-produk ini.
Fokus penguatan yang terakhir adalan peningkatan jejaring antar BUMDes yang diharapkan dapat menjadi jalan bagi terbukanya saluran baru untuk pemasaran produk serta sebagai wadah untuk saling belajar dan bertukar informasi.

\section{PERSANTUNAN}

Terima kasih kepada LPPM Universitas Jenderal Soedirman yang mendanai kegiatan pengabdian masyarakat ini. Terimakasih yang dalam juga disampaikan kepada Kepala Desa, Sekdes dan para perangkat desa, Kepala Dusun serta para peserta diskusi kelompok terarah dari berbagai kelompok masyarakat, seperti GAPOKTAN, anggota koperasi Mulya Sari, para pelaku UMKM dan pengrajin tempe, serta karang taruna, ibu dan bapak tokoh masyarakat, serta fasilitator diskusi kelompok terarah, para mahasiswa akuntansi yang tergabung dalam Himpunan Mahasiswa Jurusan (HMJ) Akuntansi FEB UNSOED atas partisipasi dan kerjasama yang baik sehingga kegiatan masyarakat dapat terlaksana secara lancar.

\section{REFERENSI}

Abidin, H Z. (2017). Pemetaan Desa untuk Percepatan Pembangunan Desa dan Kawasan Perdesaan - Badan Informasi Geospasial, Bogor. Diakses dari http://www.keuangandesa.com/ wpcontent/uploads/2017/06/Pemetaan-Desa-untuk-Percepatan-Pembangunan-Desa-danKawasanPerdesaan.pdf . diakses 25 Juli 2018

Cunningham, G. (2012). Community Economic Literacy and the" leaky Bucket”. Coady International Institute, St. Francis Xavier University.

Freitas, H., Oliveira, M., Jenkins, M., \& Popjoy, O. (1998). The Focus Group, a qualitative research method. Isrc, Merrick School of Business, University of Baltimore (MD, Eua), WP Isrc, (010298), 22.

Goncalo, J. A., Polman, E., \& Maslach, C. (2010). Can confidence come too soon? Collective efficacy, conflict and group performance over time. Organizational Behavior and Human Decision Processes, 113(1), 13-24.

Goodman, R. M., Speers, M. A., McLeroy, K., Fawcett, S., Kegler, M., Parker, E., ... Wallerstein, N. (1998). Identifying and defining the dimensions of community capacity to provide a basis for measurement. Health Education \& Behavior, 25(3), 258-278.

Greenlees, I. A., Nunn, R. L., Graydon, J. K., \& Maynard, I. W. (1999). The relationship between collective efficacy and precompetitive affect in rugby players: Testing Bandura's model of collective efficacy. Perceptual and Motor Skills, 89(2), 431-440.

Imparato, I., \& Ruster, J. (2003). Slum upgrading and participation: Lessons from Latin America. The World Bank. 
Srirejeki, dkk - Pemetaan Potensi Desa untuk Penguatan ...

Kretzmann, J. P., \& McKnight, J. (1993). Building communities from the inside out. Center for Urban Affairs and Policy Research, Northwestern University

Ljunggren, A., Huang, Z., \& Johansson, E. (2014). Repeat focus group discussions as a tool for strengthening of management capacity in a community development project in western China. Open Journal of Social Sciences, 2(12), 63.

Mwiru, M. (2015). The importance of community participation in development projects at local level: A case of Dodoma municipal council. Mzumbe University.

Pemerintah Indonesia. 2014. Undang-Undang Republik Indonesia Nomor 6 Tahun 2014 tentang Desa. Lembaran RI Tahun 2014 No. 6. Jakarta: Sekretariat Negara.

Pemerintah Indonesia. 2005. Peraturan Pemerintah No. 72 Tahun 2005 tentang Desa. Jakarta: Sekretariat Negara.

Sharma, M. (2005). Using focus groups in community based rehabilitation. Asia Pacific Disabil Rehabil $J, 16,41-50$.

Srirejeki, K. (2015). Tata Kelola Keuangan Desa. Jurnal Akuntansi Dan Bisnis, 15(1), 33-37.

Srirejeki, K. (2018). Empowering the role of village owned enterprises (BUMDes) for rural development: case of Indonesia. Jurnal Akuntansi Manajemen Dan Ekonomi, 20(1), 5-10. 